\title{
SLC6A3 and body mass index in the Prostate, Lung, Colorectal and Ovarian Cancer Screening Trial
} Elizabeth M Azzato*1,2, Lindsay M Morton ${ }^{1}$, Andrew W Bergen ${ }^{3}$, Sophia S Wang ${ }^{1}$, Nilanjan Chatterjee ${ }^{1}$, Paul Kvale ${ }^{4}$, Meredith Yeager ${ }^{5}$, Richard B Hayes ${ }^{1}$, Stephen J Chanock ${ }^{5}$ and Neil E Caporaso ${ }^{1}$

\author{
Address: ${ }^{1}$ Division of Cancer Epidemiology and Genetics, National Cancer Institute, NIH, DHHS, Rockville, Maryland, USA, ${ }^{2}$ Department of \\ Oncology, University of Cambridge, Strangeways Research Laboratory, Worts Causeway, Cambridge, CB1 8RN, UK, ${ }^{3}$ Center for Health Sciences, \\ SRI International, Menlo Park, California, USA, ${ }^{4}$ Henry Ford Health System, Detroit, Michigan, USA and ${ }^{5}$ Core Genotyping Facility, Division of \\ Cancer Epidemiology and Genetics, Advanced Technology Program, SAIC Frederick, Inc, NCI-Frederick, Frederick, Maryland, USA \\ Email: Elizabeth M Azzato* - ema32@cam.ac.uk; Lindsay M Morton - mortonli@mail.nih.gov; Andrew W Bergen - andrew.bergen@sri.com; \\ Sophia SWang - wangso@mail.nih.gov; Nilanjan Chatterjee - chattern@mail.nih.gov; Paul Kvale - pkvale1@hfhs.org; \\ Meredith Yeager - my76y@nih.gov; Richard B Hayes - hayesr@mail.nih.gov; Stephen J Chanock - sc83a@nih.gov; \\ Neil E Caporaso - caporasn@epndce.nci.nih.gov \\ * Corresponding author
}

Published: 30 January 2009

BMC Medical Genetics 2009, 10:9 doi:10.1 186/1471-2350-10-9
Received: 30 May 2008

Accepted: 30 January 2009

This article is available from: http://www.biomedcentral.com/I47/-2350/I0/9

(C) 2009 Azzato et al; licensee BioMed Central Ltd.

This is an Open Access article distributed under the terms of the Creative Commons Attribution License (http://creativecommons.org/licenses/by/2.0), which permits unrestricted use, distribution, and reproduction in any medium, provided the original work is properly cited.

\begin{abstract}
Background: To investigate the contribution of the dopamine transporter to dopaminergic reward-related behaviors and anthropometry, we evaluated associations between polymorphisms at the dopamine transporter gene(SLC6A3) and body mass index (BMI), among participants in the Prostate, Lung, Colorectal and Ovarian (PLCO) Cancer Screening Trial.

Methods: Four polymorphisms (rs6350, rs6413429, rs6347 and the $3^{\prime}$ variable number of tandem repeat (3' VNTR) polymorphism) at the SLC6A3 gene were genotyped in 2,364 participants selected from the screening arm of PLCO randomly within strata of sex, age and smoking history. Height and weight at ages 20 and 50 years and baseline were assessed by questionnaire. BMI was calculated and categorized as underweight, normal, overweight and obese $(<18.5,18.5-24.9,25.0-29.9$, or $\geq$ $30 \mathrm{~kg} / \mathrm{m}^{2}$, respectively). Odds ratios (ORs) and $95 \%$ confidence intervals $(\mathrm{Cls})$ of SLC6A3 genotypes and haplotypes were computed using conditional logistic regression.

Results: Compared with individuals having a normal BMI, obese individuals at the time of the baseline study questionnaire were less likely to possess the 3' VNTR variant allele with 9 copies of the repeated sequence in a dose-dependent model $\left(* *\right.$ is referent; $O R_{* 9}=0.80, O_{99}=0.47, p_{\text {trend }}$ $=0.005)$. Compared with individuals having a normal BMI at age 50 , overweight individuals (A-CG-* is referent; $\mathrm{OR}_{\mathrm{A}-\mathrm{C}-\mathrm{G}-9}=0.80,95 \% \mathrm{Cl} 0.65-0.99, \mathrm{P}=0.04$ ) and obese individuals (A-C-G-* is referent; $\left.\mathrm{OR}_{\mathrm{A}-\mathrm{C}-\mathrm{G}-9}=0.70,95 \% \mathrm{Cl} 0.49-0.99, \mathrm{P}=0.04\right)$ were less likely to possess the haplotype with the 3'variant allele (A-C-G-9).
\end{abstract}

Conclusion: Our results support a role of genetic variation at the dopamine transporter gene, SLC6A3, as a modifier of BMI. 


\section{Background}

Modifiable behavioral risk factors, specifically poor diet and physical inactivity, tobacco use and alcohol consumption are major causes of mortality in the United States [1]. Family, twin and adoption studies provide evidence that inherited variation makes a substantial contribution to body fat/obesity, smoking and alcohol dependence. With regard to obesity, the heritability of $\mathrm{BMI}$ is estimated to be significant and to range up to $80 \%$ in large twin samples $[2,3]$

Nearly two-thirds of the US population is overweight or obese, and increased adiposity increases risk of death from heart disease, type 2 diabetes mellitus, hypertension, and diverse cancers [4]. Mutations in leptin (LEP), prohormone convertase 1 (PCSK1), proopiomelanocortin $(P O M C)$ and melanocortin 4 receptor $(M C 4 R)$ are involved in rare monogenic recessive forms of obesity [5], but studies relying on populations with morbid obesity may not represent processes contributing to overweight and obesity in the general population. The genetic variation that contributes to susceptibility to obesity in the general population is beginning to be elucidated through candidate gene and genome wide studies focused on obesity and related phenotypes [6]. Recent genome wide association scans have identified regions in the FTO gene [7$10]$ and variants telomeric to the $M C 4 R$ gene to be associated with obesity $[11,12]$. The genes identified to date likely only identify a small proportion of the genetic variability that influences susceptibility to obesity.

Diverse lines of evidence implicate heritable differences in the dopamine reward pathway associated with the consumption of food, as well as alcohol dependence and tobacco use [13-21]. Dopamine is a key neurotransmitter mediating reward, and therefore, it is relevant to diverse behavioral conditions including obesity. SLC6A3, the dopamine transporter gene, is an important polymorphic gene which controls the reuptake of dopamine in the synapse, in areas of the CNS crucial to reward and learning such as the mesolimbic pathway. Early genetic association studies in the general population examined SLC6A3 in relation to smoking and alcohol intake $[22,23]$, and there is evidence for a relationship of SLC6A3 genotype to BMI in a small study in African Americans [24]. However, a large, representative United States population has not been studied to date.

We previously reported an association with the DRD2 TaqI and IVS6-83 variant alleles and the wild-type-239 allele with obesity $[25,26]$. In order to further evaluate the effects of common inherited variation in the dopamine pathway on BMI, we extended our study to include four polymorphisms in the gene that codes for the dopamine transporter (DAT1), SLC6A3, among 2,364 participants in the Prostate, Lung, Colorectal, and Ovarian (PLCO) Cancer Screening Trial.

\section{Methods}

\section{Study population}

The PLCO Cancer Screening Trial study population has been described previously [27]. Briefly, over 150,000 individuals aged 55-74 years from ten US study centers were randomized during 1992-2001 to undergo a specific cancer screening regimen or receive routine medical care to evaluate the effects of screening on disease-specific mortality. At entry into the trial, participants provided written, informed consent and completed a baseline demographic and risk factor questionnaire. Participants in the screening arm were also asked to provide separate written, informed consent and a blood sample for use in etiologic studies.

Adult height and weight at baseline and ages 20 and 50 were obtained from the baseline questionnaire. Body mass index (BMI, $\left.\mathrm{kg} / \mathrm{m}^{2}\right)$ was computed. Individuals were characterized at each age as underweight, normal weight, overweight, or obese. Information on the smoking habits of smokers and alcohol consumption were obtained in the baseline questionnaire; non-smokers were defined as individuals who had never smoked cigarettes regularly for at least six months. Additional information on race/ethnicity, highest level of schooling completed and marital status were also obtained from the baseline questionnaire.

\section{Design}

We originally selected a sample for investigations of behavioral characteristics (smoking, alcohol dependence and BMI) related to cancer, and we have reported the smoking results $[25,28]$. The sample consisted of 2,406 participants selected randomly after stratifying by sex, age (55-59, 60-64, 65-69, 70-74 years), smoking status (never, current, former), and quantity of cigarettes smoked for current and former smokers (1-10, 11-20, $21+$ cigarettes per day). Blood samples with sufficient DNA for genotyping were available for 2,379 (98.9\%) of these individuals. An additional 15 individuals were excluded due to missing data for BMI at all three time points (ages 20 and 50 years and baseline), yielding a final analytic population of 2,364 participants. This study was conducted according to a protocol approved by the Institutional Review Board of the National Cancer Institute.

\section{Genotyping}

We selected for genotyping three single nucleotide polymorphisms (SNPs) and one variable number of tandem repeat (VNTR) polymorphism in SLC6A3 (see Additional file 1, Supplemental table 1). Two of the selected SNPs, SLC6A3 1215A>G (Ex9-55; S405S) and SLC6A3 114C>T $(\mathrm{Ex} 2+159 ; \mathrm{N} 38 \mathrm{~N})$ are in the coding region of SLC6A3. The third SNP, SLC6A3 -3714G>T, is located in the 5' non- 
coding region. With respect to the SLC6A3 VNTR genotype, the * symbol designates any VNTR allele other than the 9 allele. We also evaluated four SNPs in DRD2/ ANKK1, which have been previously reported [25] for a possible gene-gene effect (see Additional file 1, Supplemental table 1). All polymorphisms were chosen based on biologic plausibility, previous research, availability of functional data, potential linkage disequilibrium with other functional SNPs, and minor allele frequency greater than 5\% [29]. DNA extraction and genotyping and quality control data are reported elsewhere [25].

\section{Statistical analysis}

Hardy-Weinberg equilibrium was evaluated among nonHispanic Caucasians for each polymorphism by comput- ing the Pearson chi-square statistic. Haplotypes were visualized using Haploview, version 3.11, based on measures of pairwise linkage disequilibrium between polymorphisms. SAS/Genetics, version 8.2 (SAS Institute, Inc., Cary, NC), was used to generate maximum likelihood estimates of haplotype frequencies and to assign the most probable haplotypes for each individual. Haplotypes with an estimated frequency of greater than $1 \%$ were considered in our analyses. Individuals with missing values for one or more genotypes were excluded from the haplotype analyses for that gene. As haplotype analyses are potentially more sensitive to ethnic variation, these analyses were limited to non-Hispanic Caucasians only. The probability of the assigned haplotype pair was greater than $99 \%$ for approximately $80 \%$ of individuals.

Table I: Selected characteristics of study participants from the Prostate, Lung, Colorectal and Ovarian Cancer Screening Trial (PLCO)

\begin{tabular}{|c|c|c|c|c|}
\hline & \multicolumn{4}{|c|}{ Current BMI* } \\
\hline & Underweight & Normal & Overweight & Obese \\
\hline & $N=26$ & $N=898$ & $N=989$ & $N=443$ \\
\hline \multicolumn{5}{|l|}{ Gender, \# (\%) } \\
\hline Male & $4(15.4)$ & $380(42.3)$ & $571(57.7)$ & $232(52.4)$ \\
\hline Female & $22(84.6)$ & $518(57.7)$ & $418(42.3)$ & $211(47.6)$ \\
\hline \multicolumn{5}{|l|}{ Age in yrs, \# (\%) } \\
\hline $50-59$ & $3(11.5)$ & $218(24.2)$ & $248(25.1)$ & $126(28.4)$ \\
\hline $60-64$ & $7(26.9)$ & $194(21.6)$ & $268(27.1)$ & $128(28.9)$ \\
\hline $65-69$ & $8(30.8)$ & $254(28.3)$ & $258(26.1)$ & $108(24.4)$ \\
\hline $70-74$ & $8(30.8)$ & $232(25.8)$ & $215(21.7)$ & $81(18.3)$ \\
\hline \multicolumn{5}{|l|}{ Race, \# (\%) } \\
\hline Caucasian & $23(88.5)$ & $799(89.0)$ & $888(89.8)$ & $359(81.0)$ \\
\hline African American & I (3.8) & $37(4.1)$ & $43(4.3)$ & $30(6.7)$ \\
\hline Other & $2(7.7)$ & $62(6.9)$ & $58(5.9)$ & $18(4.1)$ \\
\hline \multicolumn{5}{|l|}{ Education, \# (\%) } \\
\hline$<=12$ years & $14(53.8)$ & $264(29.4)$ & $306(31.0)$ & $165(37.3)$ \\
\hline Some College & $7(26.9)$ & $318(35.5)$ & $376(38.1)$ & $167(37.7)$ \\
\hline College grad. & $5(19.2)$ & $315(35.1)$ & $305(30.9)$ & $110(24.9)$ \\
\hline Missing & $0(0.0)$ & I (0.002) & $2(0.002)$ & I (0.003) \\
\hline \multicolumn{5}{|l|}{ Marital Status, \# (\%) } \\
\hline Married/living as married & $14(53.8)$ & $613(68.3)$ & $716(72.4)$ & $313(70.7)$ \\
\hline Unmarried & $12(46.2)$ & $285(31.7)$ & $271(27.4)$ & $103(23.3)$ \\
\hline Missing & $0(0.0)$ & $0(0.0)$ & $2(0.002)$ & $0(0.0)$ \\
\hline \multicolumn{5}{|l|}{ Smoking Status, \# (\%) } \\
\hline Never & $3(11.5)$ & $81(9.0)$ & $84(8.5)$ & $43(9.7)$ \\
\hline Current & $19(73.1)$ & $46 \mid(5 I .3)$ & $434(43.9)$ & $146(33.0)$ \\
\hline Former & $4(15.4)$ & $356(39.6)$ & $471(47.6)$ & $254(57.3)$ \\
\hline \multicolumn{5}{|l|}{ Cigarettes per day, \# (\%) } \\
\hline $1-10$ & $8(34.8)$ & $286(35.0)$ & $286(31.6)$ & $135(33.8)$ \\
\hline $11-20$ & $9(39.1)$ & $286(35.0)$ & $316(34.9)$ & III (27.8) \\
\hline $21+$ & $6(26.1)$ & $245(30.0)$ & $303(33.5)$ & $154(38.5)$ \\
\hline
\end{tabular}

* BMl categorized as Underweight $\left(\leq 18 \mathrm{~kg} / \mathrm{m}^{2}\right)$, Normal $\left(18-24.9 \mathrm{~kg} / \mathrm{m}^{2}\right)$, Overweight $\left(25-29.9 \mathrm{~kg} / \mathrm{m}^{2}\right)$ or Obese $\left(\geq 30 \mathrm{~kg} / \mathrm{m}^{2}\right)$; data on BMl at baseline were missing for $\mathrm{N}=8$ individuals. 
Individuals were characterized at each age as underweight, normal weight, overweight, or obese $(<18.5,18.5-24.9$, $25.0-29.9$, or $\geq 30 \mathrm{~kg} / \mathrm{m}^{2}$, respectively). Change in weight over time was assessed in two ways. First, individuals were categorized into four groups based on percent change in weight from age 20 to age 50 and from age 20 to current age $(\leq 10 \%, 10.1-20.0 \%, 20.1-30.0 \%$, or $>30.0 \%)$. Second, change in weight per 10 years was computed by regressing BMI at ages 20,50 and age at a baseline measurement recorded at study enrollment against age. The slope of each regression line was then characterized into four groups $(\leq 0.30,0.31-0.70,0.71-1.20$, or $>1.20 \mathrm{~kg} /$ $\mathrm{m}^{2}$ per 10 years). This slope of BMI change corresponds to a change in weight, as height was only reported once at the time of baseline questionnaire. Intensity of cigarette smoking was categorized as light, medium, or heavy (1$10,11-20$, or $\geq 21$ cigarettes per day, respectively).

Cross sectional analysis was conducted to compare individuals by behavioral characteristics at baseline (obese, overweight, or underweight versus normal weight individuals, smoking status and alcohol use), to compare individuals by percent change in weight from age 20 to current age $(10.1-20.0 \%, 20.1-30.0 \%$ or $>30.0 \%$ versus $\leq 10 \%)$ and finally to compare individuals by BMI slope, the change in weight per 10 years $(0.31-0.70,0.71-1.20$, or > 1.20 versus $\leq 0.30 \mathrm{~kg} / \mathrm{m}^{2}$ per 10 years $)$.

The sample was originally selected to examine behavioral characteristics relevant to cancer (smoking, alcohol use and BMI), so data had been sampled by categories of current smoking status and cigarettes per day, age group and gender. Differences between comparison groups in the distribution of SCL6A3 gene variants were quantified using multivariate conditional logistic regression models, conditioned on the variables used to construct the stratified sample (sex, age, smoking status, and quantity of cigarettes smoked for current and former smokers). Conditional logistic regression was necessary, as the original study design involved sampling according to these variables. In such a case, conditional logistic regression most appropriately models the sampling frame to obtain proper risk estimates. Attempts to conduct an unconditional logistic regression including all strata terms resulted in non-convergence of the model.

Odds ratios (ORs) and 95\% confidence intervals (CIs) were computed for individual genotypes with the common allele homozygote as the referent. In the case of haplotypes, data were analyzed with the haplotype containing the most common allele for each locus as the referent. Using an additive (dose-dependent) model, we also computed a p-value for the linear trend based on a three-level variable for each genotype (common allele homozygote, heterozygote, variant allele homozygote); this is equiva- lent to a dose-dependent effect with regard to the number of copies of the variant allele. Finally, adjusted analyses on baseline BMI and SLCGA3 genotype were conducted stratified by DRD2 haplotype, to evaluate a possible interaction between DRD2 and SLC6A3.

All models were also adjusted for self-identified race/ethnicity (Caucasian, African American, other). Inclusion of additional demographic factors, such as alcohol use, education, and marital status, in the models did not substantially modify the parameter estimates $( \pm 10 \%)$ and were therefore excluded from the model. The SAS System, version 9.1 (SAS Institute, Inc., Cary, NC), was used to conduct all statistical analyses. P-values are presented with one significant digit. Statistical tests were two-sided with an $\alpha$-level of 0.05 .

\section{Results}

Genotype concordance rate was greater than $97 \%$. We observed no significant deviation from Hardy-Weinberg equilibrium for any of the polymorphisms (all p > 0.80).

Underweight, normal weight, overweight, and obese individuals differed significantly by gender $(\mathrm{p}<0.0001)$, age $(\mathrm{p}=0.006)$, education $(\mathrm{p}=0.0008)$, smoking status $(\mathrm{p}<$ 0.0001 ) and cigarettes per day (among smokers, $\mathrm{p}=0.04$ ) (Table 1). Specifically, obese individuals tended to be male, younger, less highly educated, married, and former smokers.

BMI was significantly associated with SLC6A3 polymorphisms and haplotypes (Table 2). Compared with individuals with normal BMI at baseline, obese individuals $\left(\mathrm{BMI} \geq 30 \mathrm{~kg} / \mathrm{m}^{2}\right)$ were less likely to possess the SLC6A3 VNTR variant allele ( 9 copies of the VNTR) in a dosedependent model $\left({ }^{* *}\right.$ is referent; $\mathrm{OR}_{* 9}=0.80, \mathrm{OR}_{99}=$ $0.47, \mathrm{p}_{\text {trend }}=0.005$ ). Consistent with the single polymorphism analyses, obese individuals at baseline were less likely than individuals with normal $\mathrm{BMI}$ to possess the haplotype with the SLC6A3 VNTR variant allele (A-C-G-9) (A-C-G-* is referent; $\mathrm{OR}_{\mathrm{A}-\mathrm{C}-\mathrm{G}-9}=0.60,95 \%$ CI $0.45-0.80$, $\mathrm{p}=0.001$ ). Results were consistent for the analysis at age 50. Compared with individuals with normal $\mathrm{BMI}$ at age 50 , overweight individuals (A-C-G- ${ }^{*}$ is referent; $\mathrm{OR}_{\mathrm{A}-\mathrm{C}-\mathrm{G}-9}$ $=0.80,95 \%$ CI $0.65-0.99, \mathrm{p}=0.04)$ and obese individuals (A-C-G-* is referent; $\mathrm{OR}_{\mathrm{A}-\mathrm{C}-\mathrm{G}-9}=0.70,95 \%$ CI 0.49 $0.99, \mathrm{p}=0.04$ ) were less likely to possess the haplotype with the SLC6A3 variant allele (A-C-G-9). No significant trends were noted at age 20 .

Compared with individuals having a normal BMI, underweight individuals (BMI $\left.<18.5 \mathrm{~kg} / \mathrm{m}^{2}\right)$ at the time of the baseline study questionnaire were significantly more likely to possess the variant allele for the SLC6A3 polymorphism Ex9-55A>G in a dose-dependent model (AA is 
Table 2: SLC6A3 polymorphisms and haplotypes by body mass index

\begin{tabular}{|c|c|c|c|c|c|c|c|c|c|c|c|c|c|}
\hline \multirow[b]{2}{*}{ Polymorphism } & \multirow{2}{*}{$\frac{\text { Normal }}{\mathbf{N}}$} & \multicolumn{4}{|c|}{ Underweight BMI $\dagger$} & \multicolumn{4}{|c|}{ Overweight BMI† } & \multicolumn{4}{|c|}{ Obese BMI $\dagger$} \\
\hline & & $\mathbf{N}$ & OR $\ddagger$ & $(95 \% \mathrm{Cl})$ & $\mathbf{P}$ & $\mathbf{N}$ & OR $\ddagger$ & $(95 \% \mathrm{Cl})$ & $\mathbf{P}$ & $\mathbf{N}$ & OR $\ddagger$ & $(95 \% \mathrm{Cl})$ & $\mathbf{P}$ \\
\hline \multicolumn{14}{|l|}{ SLC6A3 VNTR } \\
\hline$* *$ & 459 & 14 & 1.00 & (reference) & & 514 & 1.00 & (reference) & & 254 & 1.00 & (reference) & \\
\hline$* 9$ & 361 & 12 & 1.07 & $(0.48,2.38)$ & 0.870 & 390 & 0.93 & $(0.76,1.13)$ & 0.459 & 159 & 0.80 & $(0.62,1.04)$ & 0.093 \\
\hline 99 & 67 & 0 & $\sim$ & & & 63 & 0.81 & $(0.56,1.19)$ & 0.284 & 19 & 0.47 & $(0.27,0.83)$ & 0.009 \\
\hline$P$ for trend & & & & & & & & $p=0.246$ & & & & $p=0.005$ & \\
\hline$* 9 / 99$ & & & 0.91 & $(0.4 I, 2.0 I)$ & 0.809 & & 0.91 & $(0.75,1.10)$ & 0.332 & & 0.75 & $(0.59,0.96)$ & 0.023 \\
\hline \multicolumn{14}{|l|}{$E \times 9-55 A>G$} \\
\hline AA & 498 & 8 & 1.00 & (reference) & & 539 & 1.00 & (reference) & & 220 & 1.00 & (reference) & \\
\hline AG & 338 & 14 & 2.66 & $(1.08,6.58)$ & 0.034 & 369 & 1.03 & $(0.85,1.25)$ & 0.771 & 193 & 1.34 & $(1.04,1.73)$ & 0.023 \\
\hline GG & 59 & 4 & 6.12 & $(1.66,22.6 I)$ & 0.007 & 80 & 1.25 & $(0.86,1.82)$ & 0.234 & 27 & 0.99 & $(0.60,1.66)$ & 0.981 \\
\hline$P$ for trend & & & & $p=0.003$ & & & & $p=0.329$ & & & & $p=0.152$ & \\
\hline AG/GG & & & 3.04 & $(1.28,7.24)$ & 0.012 & & 1.06 & $(0.88,1.28)$ & 0.533 & & 1.29 & $(1.01,1.65)$ & 0.042 \\
\hline \multicolumn{14}{|l|}{ Haplotype $\S$} \\
\hline A-C-G-* & 795 & 22 & 1.00 & (reference) & & 906 & 1.00 & (reference) & & 419 & 1.00 & (reference) & \\
\hline A-C-G- $\underline{9}$ & 251 & 3 & 0.44 & $(0.13,1.49)$ & 0.187 & 252 & 0.85 & $(0.69,1.05)$ & 0.126 & 84 & 0.60 & $(0.45,0.80)$ & 0.001 \\
\hline A-I-I- $*$ & 86 & 0 & $\sim$ & & & 81 & 0.90 & $(0.65,1.25)$ & 0.529 & 34 & 0.79 & $(0.51,1.23)$ & 0.298 \\
\hline G-C-G-* & 213 & 10 & 1.84 & $(0.83,4.05)$ & 0.132 & 242 & 1.03 & $(0.83,1.28)$ & 0.761 & 124 & 1.15 & $(0.88,1.50)$ & 0.319 \\
\hline 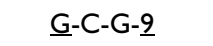 & 173 & 7 & 1.51 & $(0.62,3.70)$ & 0.369 & 200 & 1.00 & $(0.79,1.26)$ & 0.988 & 75 & 0.88 & $(0.64,1.20)$ & 0.408 \\
\hline
\end{tabular}

$*=$ an allele other than the SLC6A3*9 allele. These are largely $(98.1 \%)$ the SLC6A3*10 VNTR allele.

† BMI categorized as Underweight $\left(\leq 18 \mathrm{~kg} / \mathrm{m}^{2}\right)$, Normal $\left(18-24.9 \mathrm{~kg} / \mathrm{m}^{2}\right)$, Overweight $\left(25-29.9 \mathrm{~kg} / \mathrm{m}^{2}\right)$ or Obese $\left(\geq 30 \mathrm{~kg} / \mathrm{m}^{2}\right)$.

$\ddagger$ OR estimated using conditional logistic regression, conditioning on age, sex, current smoking status, number of cigarettes smoked.

$\S$ Haplotype analyses were conducted among non-Hispanic Caucasians.

referent; $\left.\mathrm{OR}_{\mathrm{AG}}=2.7, \mathrm{OR}_{\mathrm{GG}}=6.1, \mathrm{p}_{\text {trend }}=0.003\right)($ Table 2). Results from the haplotype analyses were consistent with those from the single polymorphism analyses (Table 2).

Percent change in weight and weight change slope were also associated with SLC6A3 haplotypes, although the association between individual polymorphisms and percent change in weight did not achieve statistical significance. Individuals who carried the 9 VNTR allele on a wild-type background for the other SNPs (A-C-G-9) were less likely to significantly increase their weight from age 20 to age 50 (Table 3). Similarly, individuals with this haplotype were less likely to experience rapid weight gain (increased slope of weight change) from age 20 to the time of the baseline questionnaire (see Additional file 1, Supplemental table 2).

We found no evidence of interaction between polymorphisms at SLC6A3 and DRD2/ANKK1. Among individuals with the DRD2/ANKK1 haplotype (T-C-T-A) previously associated with obesity [25], no marked increase in effect of the SLC6A3 VNTR on obesity was observed $\left(^{* *}=\right.$ reference; $\mathrm{OR}_{* 9}=0.89,95 \%$ CI $0.54-1.46 ; \mathrm{OR}_{99}=0.54,95 \%$ CI $0.23-1.33$, p-value for interaction $=0.62$ ).

Analyses restricted to non-Hispanic Caucasians were consistent with the findings above (data not shown).
We did not observe any significant associations of the SLC6A3 polymorphisms with any of the smoking outcomes (number cigarettes per day, smoking duration, age at initiation, pack years) or alcohol consumption.

\section{Discussion}

We report a protective effect of the 9 allele of the SLC6A3 VNTR on overweight and obesity and a novel association between the presence of the $\mathrm{G}$ allele of $S L C 6 A 3 \mathrm{Ex} 9$ $55 \mathrm{~A}>\mathrm{G}$ polymorphism and being underweight. These results support the role of genetic variation at the dopamine transporter locus as modifiers of body weight and extend our earlier findings that polymorphisms in the D2 dopamine receptor are associated with both cigarette smoking and obesity $[25,26]$, suggesting that multiple genes in the dopaminergic system influence these behaviors.

Dopaminergic function may modulate reward from both food and drugs of abuse. This reward deficiency hypothesis (constitutional anhedonia predisposing individuals to reliance on extrinsic stimuli such as food, nicotine or alcohol) provides the dominant framework in molecular genetic studies of dopaminergic function and its effects on drug addiction (e.g., [30,31]). This model has also motivated, in part, interpretation of neuroimaging based studies, which have provided molecular and functional 
Table 3: SLC6A3 polymorphisms and haplotypes by percent change in weight

\begin{tabular}{|c|c|c|c|c|c|c|c|c|c|}
\hline \multirow[b]{3}{*}{$\begin{array}{l}\text { Polymorphis } \\
\text { m }\end{array}$} & \multirow{3}{*}{\multicolumn{2}{|c|}{$\mathbf{N}$}} & \multirow[b]{3}{*}{ G Freq (\%) } & \multicolumn{6}{|c|}{$\%$ Change in weight from age 20 to age 50} \\
\hline & & & & \multicolumn{2}{|c|}{$\begin{array}{c}5 .|-| 5.0 \%(N=806) \text { vs. } \leq 5 \% \\
(N=5 \mid 5)\end{array}$} & \multicolumn{2}{|c|}{$\begin{array}{c}\text { 15. } \mid-25.0 \%(N=524) \text { vs. } \leq \\
5 \%(N=5 \mid 5)\end{array}$} & \multicolumn{2}{|c|}{ 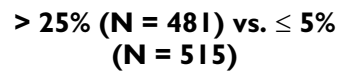 } \\
\hline & & & & OR $\ddagger$ & $(95 \% \mathrm{Cl})$ & OR $\ddagger$ & $(95 \% \mathrm{Cl})$ & OR $\ddagger$ & $(95 \% \mathrm{Cl})$ \\
\hline \multirow{2}{*}{$\begin{array}{l}\text { SLC6A3 } \\
\text { VNTR }\end{array}$} & $* 9$ & 724 & 39.9 & 0.88 & $(0.70,1.13)$ & 0.92 & $(0.71,1.20)$ & 0.90 & $(0.68,1.18)$ \\
\hline & 99 & 119 & 6.5 & 1.10 & $(0.70,1.73)$ & 0.70 & $(0.41,1.22)$ & 0.64 & $(0.36,1.14)$ \\
\hline \multirow[t]{2}{*}{$E \times 9-55 A>G$} & AG & 711 & 39.0 & 1.16 & $(0.91,1.48)$ & 1.28 & $(0.98,1.67)$ & 1.14 & $(0.87,1.50)$ \\
\hline & GG & 138 & 7.2 & 0.86 & $(0.56,1.34)$ & 0.96 & $(0.60,1.54)$ & 0.70 & $(0.41,1.20)$ \\
\hline \multirow[t]{2}{*}{$\mathrm{Ex} 2+159 \mathrm{C}>\mathrm{T}$} & $\mathrm{CT}$ & 188 & 10.8 & 1.02 & $(0.70,1.47)$ & 1.06 & $(0.71,1.57)$ & 0.87 & $(0.56,1.35)$ \\
\hline & TT & 6 & 0.4 & 0.76 & $(0.14,4.17)$ & 0.82 & $(0.13,5.09)$ & 0.46 & $(0.08,2.76)$ \\
\hline \multirow[t]{2}{*}{$-37 \mid 4 G>T$} & $\mathrm{GT}$ & 194 & 11.1 & 1.01 & $(0.70,1.45)$ & 1.17 & $(0.80,1.73)$ & 0.80 & $(0.51,1.24)$ \\
\hline & TT & 8 & 0.5 & 0.74 & $(0.15,3.56)$ & 0.92 & $(0.18,4.78)$ & 0.48 & $(0.08,2.87)$ \\
\hline \multicolumn{10}{|l|}{ Haplotype $†$} \\
\hline A-C-G-* & & 2153 & 50.9 & 1.00 & (reference) & 1.00 & (reference) & 1.00 & (reference) \\
\hline A-C-G- 9 & & 596 & 14.1 & 0.92 & $(0.72,1.18)$ & 0.74 & $(0.56,0.98)$ & 0.70 & $(0.52,0.94)$ \\
\hline A-T-T-* & & 202 & 4.8 & 1.15 & $(0.76,1.73)$ & 1.23 & $(0.79,1.93)$ & 0.94 & $(0.57,1.53)$ \\
\hline G-C-G-* & & 592 & 14 & 1.05 & $(0.82,1.36)$ & 1.12 & $(0.85,1.47)$ & 0.91 & $(0.68,1.23)$ \\
\hline G-C-G- $\underline{9}$ & & 456 & 10.8 & 1.07 & $(0.81,1.43)$ & 1.12 & $(0.82,1.53)$ & 0.96 & $(0.69,1.34)$ \\
\hline
\end{tabular}

$*=$ an allele other than the SLC6A3*9 allele. These are largely (98.1\%) the SLC6A3*10 VNTR allele.

† Haplotype analyses were conducted among non-Hispanic Caucasians

$\ddagger$ OR estimated using conditional logistic regression, conditioning on age, sex, current smoking status, number of cigarettes smoked

neuroanatomical evidence on the relationship between dopaminergic function and drug addiction or obesity [32].

The dopamine transporter (DAT1, SLC6A3) is responsible for the reuptake of dopamine into the presynaptic dopaminergic cell from the dopamine synapse. The SLC6A3 VNTR polymorphism has been considered to be functional based on a relation of the repeats to regulation of promoter activity. in vitro and ex vivo studies involving human tissues have shown that the SLC6A3* 10 allele has been associated with increased concentrations of DAT protein, when compared with the $S L C 6 A 3 * 9$ allele [3336], although neuroimaging approaches involving indirect estimation of striatal DAT levels by antagonist displacement and single photon emission computed tomography (SPECT) have not revealed consistent differences in DAT levels between 9 and 10 repeats [37-40]. Mechanistically, increasing the number of variable repeats appears to result in higher concentrations of the DAT protein. This, in turn, may lead to higher dopamine transporter binding and more efficient dopamine clearance, resulting in lower postsynaptic concentrations of dopamine. Presence of "faster" dopamine reuptake, as seen with the 10 repeat allele, may affect the reinforcing value of food.
This present study supports the association between the presence of the 9 allele of SLC6A3 VNTR and decreased risk of obesity. Our findings are supported by earlier work of Epstein et al, who first reported the association of the 10 allele and obesity in African American smokers [24]. A recent study evaluating polymorphisms in genes involved in dopamine availability in a UK cohort of Caucasian females did not find this association; however, the study was not sufficiently large enough to detect an effect of the size that we detected at the SLC6A3 VNTR [41]. Another recent study did not report an association with the SLC6A3 VNTR and BMI, but this study was based on an adolescent cohort, which had large demographic differences from our study [42]. Also, although recent genome wide association studies have identified common genetic variation in the melanocortin 4 receptor $(M C 4 R)$ and FTO (the fat mass and obesity associated) genes, an association with the dopamine transporter was not reported [7$9,11,12]$. However, it is important to stress that genomewide association studies do not capture all genetic variation in the human genome (for example, variants with $\mathrm{MAF}<5 \%$ are often completely absent); therefore, candidate gene studies will continue to be important to verify and provide more detailed analyses of biologically plausible candidates [43]. 
This present study also supports an association between presence of the G allele of $S L C 6 A 3$ Ex9-55A>G polymorphism and being underweight. Although this relationship is statistically striking, further study is required to validate this finding. However, dopamine dysregulation is present in anorexia nervosa. For example, increased central dopaminergic activity is observed in weight-recovered anorectics compared to controls [44], and dopamine D2 and D4 receptor polymorphisms have been associated with anorexia $[45,46]$. At present, it is unknown if the SLC6A3 Ex9-55A $>$ G polymorphism represents a functional variant. It is possible that this variant influences transcription, transcript stability or translation [47] or that it is in linkage disequilibrium with a functional polymorphism; exon 9 and the VNTR polymorphism have been reported to be in linkage disequilibrium [48].

Smoking and being overweight are related [49] and both increase the risk of death from the major causes of mortality including heart disease, diabetes and cancer [50-53]. As expected, we saw a significant difference in smoking status by BMI, with former smokers more likely to be obese than their smoking counterparts. This association has been previously described, as well as weight gain after smoking cessation [54,55]. Previous studies have shown that this association may be due to a relationship between food reinforcement and dopamine genotypes in smokers, as smoking cessation decreases the activation of the reward pathway, resulting in the substitution of food for cigarettes [56]. Earlier work suggested an interaction of the dopamine receptor and transporter on both smoking and cessation outcome $[57,58]$. As smoking and being overweight are related $[49,54,55]$ and the same genetic polymorphisms involved in the dopaminergic reward pathway that regulates food reward may also influence reward from nicotine, it is reasonable to postulate that $D R D 2$ and the dopamine transporter interact to increase their effects on BMI. Although we failed to observe formal statistical interaction (supraadditive or multiplicative effect) of the two genes, the additive effects observed are consistent with effects of both genes on obesity.

It is important to note some limitations with this study. We relied on self-report data for height and weight to calculate BMI. This type of self-report data has an inherent degree of misclassification, which can bias results towards the null. In order to minimize this misclassification error, we categorized BMI by established, broad categories. Use of this classification is widely accepted in the literature but does slightly reduce power; the original continuous BMI variable would have provided a slightly more powerful test for association with the genetic polymorphisms. Also, although our study size was substantial for a study of this type, reliable detection of interaction or subgroup effects generally requires much larger study samples or consortia.

\section{Conclusion}

This study has identified an association of a functional polymorphism at a key dopaminergic locus, the dopamine transporter (SLC6A3), and BMI. The direction of this allelic effect is consistent with prior functional studies, suggesting that reduced reuptake of dopamine is protective against overweight and obesity, as well as increases in BMI. Further study of the relationships between the dopaminergic system and BMI is warranted, including taking into account sensitivity to reward as a factor influencing both diet and exercise [59].

\section{Competing interests}

The authors declare that they have no competing interests.

\section{Authors' contributions}

EMA was involved in conception and design of the study, acquisition of data, analysis and interpretation of data, and drafting of the manuscript. LMM and AWB were involved in conception and design of the study, acquisition of data, statistical analysis, analysis and interpretation of data, supervision of the study, and critical review of the manuscript. SSW was involved in conception and design of the study, obtaining funding, acquisition of data, statistical analysis, administrative, technical or material support, and supervision of the study. NC was involved in statistical analysis, analysis and interpretation of data, and critical revision of the manuscript for important intellectual content. PK was involved in analysis and interpretation of data, administrative, technical or material support, and critical revision of the manuscript for important intellectual content. MY and RBH provided administrative, technical or material support and manuscript review. SJC was involved in analysis and interpretation of data and provided administrative, technical or material support. NEC was involved in conception and design of the study, obtaining funding, acquisition of data, analysis and interpretation of data, supervision of the study, administrative, technical or material support, drafting the manuscript and critical revision of the manuscript for important intellectual content. All authors read and approved the final manuscript.

\section{Additional material}

\section{Additional file 1}

Supplemental tables. This file includes Supplemental tables referenced in the main manuscript, including Supplemental table 1: Selected polymorphisms at SLC6A3, DRD2 and ANKK1, Supplemental table 2: SLC6A3 polymorphisms and haplotypes by the slope of weight change.

Click here for file

[http://www.biomedcentral.com/content/supplementary/14712350-10-9-S1.doc] 


\section{Acknowledgements}

Robert Welch was a friend, valued colleague and important contributor to this work. We acknowledge his scientific input, technical expertise, administrative skill and warm personal support that were all integral to the success of this project. His untimely death was a loss that continues to be deeply felt by our entire community.

This project has been funded in whole or in part with federal funds from the National Cancer Institute, National Institutes of Health, under contract NOI-CO-I2400. The content of this publication does not necessarily reflect the views or policies of the Department of Health and Human Services, nor does mention of trade names, commercial products, or organizations imply endorsement by the U.S. Government. EMA was funded through the Clinical Research Training Program, a public-private partnership supported jointly by the NIH and Pfizer Inc (via a grant to the Foundation for $\mathrm{NIH}$ from Pfizer Inc) and is currently funded through the $\mathrm{NCl}$ and the NIH/University of Cambridge Graduate Partnership Program. AWB was supported by the Intramural Research Program of the National Cancer Institute and is supported by UOI DA020830.

\section{References}

I. Mokdad AH, Marks JS, Stroup DF, Gerberding JL: Actual causes of death in the United States, 2000. Jama 2004, 29I(10): I 238-1245.

2. Bell CG, Walley AJ, Froguel P: The genetics of human obesity. Nat Rev Genet 2005, 6(3):22I-234.

3. Maes $\mathrm{HH}$, Neale MC, Eaves LJ: Genetic and environmental factors in relative body weight and human adiposity. Behav Genet 1997, 27(4):325-35I.

4. Ogden CL, Carroll MD, Curtin LR, McDowell MA, Tabak CJ, Flegal KM: Prevalence of overweight and obesity in the United States, I999-2004. JAMA 2006, 295(I3): I 549-I555.

5. Farooqi IS, O'Rahilly S: Monogenic obesity in humans. Annu Rev Med 2005, 56:443-458.

6. Rankinen T, Zuberi A, Chagnon YC, Weisnagel SJ, Argyropoulos G, Walts B, Perusse L, Bouchard C: The human obesity gene map: the 2005 update. Obesity (Silver Spring) 2006, I 4(4):529-644.

7. Frayling TM, Timpson NJ, Weedon MN, Zeggini E, Freathy RM, Lindgren CM, Perry JR, Elliott KS, Lango H, Rayner NW, et al.: A common variant in the FTO gene is associated with body mass index and predisposes to childhood and adult obesity. Science 2007, 3 I 6(5826):889-894.

8. Scott LJ, Mohlke KL, Bonnycastle LL, Willer CJ, Li Y, Duren WL, Erdos MR, Stringham HM, Chines PS, Jackson AU, et al.: A genomewide association study of type 2 diabetes in Finns detects multiple susceptibility variants. Science 2007, 3 | 6(5829): | 34 |- | 345.

9. Zeggini E, Weedon MN, Lindgren CM, Frayling TM, Elliott KS, Lango H, Timpson NJ, Perry JR, Rayner NW, Freathy RM, Barrett JC, Shields B, Morris AP, Ellard S, Groves C], Harries LW, Marchini JL, Owen KR, Knight B, Cardon LR, Walker M, Hitman GA, Morris AD, Doney AS, Wellcome Trust Case Control Consortium (WTCCC), McCarthy MI, Hattersley AT: Replication of genome-wide association signals in UK samples reveals risk loci for type 2 diabetes. Science 2007, 3 | 6(5829): | 336-I34I.

10. Dina C, Meyre D, Gallina S, Durand E, Korner A, Jacobson P, Carlsson LM, Kiess W, Vatin V, Lecoeur C, Delplanque J, Vaillant E, Pattou F, Ruiz J, Weill J, Levy-Marchal C, Horber F, Potoczna N, Hercberg S, Le Stunff $C$, Bougnères $P$, Kovacs $P$, Marre $M$, Balkau $B$, Cauchi $S$, Chèvre JC, Froguel P: Variation in FTO contributes to childhood obesity and severe adult obesity. Nat Genet 2007, 39(6):724-726.

II. Chambers JC, Elliott P, Zabaneh D, Zhang W, Li Y, Froguel P, Balding

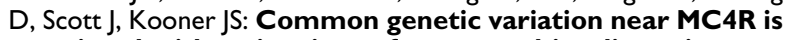
associated with waist circumference and insulin resistance. Nat Genet 2008, 40(6):716-7I8.

12. Loos RJ, Lindgren CM, Li S, Wheeler E, Zhao JH, Prokopenko I, Inouye M, Freathy RM, Attwood AP, Beckmann JS, et al.: Common variants near MC4R are associated with fat mass, weight and risk of obesity. Nat Genet 2008, 40(6):768-775.

13. Bowirrat A, Oscar-Berman M: Relationship between dopaminergic neurotransmission, alcoholism, and Reward Deficiency syndrome. Am J Med Genet B Neuropsychiatr Genet 2005, I32B(I):29-37.

14. Drago J, Padungchaichot P, Accili D, Fuchs S: Dopamine receptors and dopamine transporter in brain function and addictive behaviors: insights from targeted mouse mutants. Dev Neurosci 1998, 20(2-3): 188-203.

15. Lerman C, Caporaso NE, Audrain J, Main D, Bowman ED, Lockshin $B$, Boyd NR, Shields PG: Evidence suggesting the role of specific genetic factors in cigarette smoking. Health Psychol 1999, I8(I): |4-20.

16. Martel $\mathrm{P}$, Fantino $\mathrm{M}$ : Mesolimbic dopaminergic system activity as a function of food reward: a microdialysis study. Pharmacol Biochem Behav 1996, 53(1):221-226.

17. Saelens BE, Epstein LH: Reinforcing value of food in obese and non-obese women. Appetite 1996, 27(I):4I-50.

18. Salamone JD: The involvement of nucleus accumbens dopamine in appetitive and aversive motivation. Behav Brain Res 1994, 6 I(2): I I7-133.

19. Shields PG, Lerman C, Audrain J, Bowman ED, Main D, Boyd NR, Caporaso NE: Dopamine D4 receptors and the risk of cigarette smoking in African-Americans and Caucasians. Cancer Epidemiol Biomarkers Prev 1998, 7(6):453-458.

20. Tupala E, Tiihonen J: Dopamine and alcoholism: neurobiological basis of ethanol abuse. Prog Neuropsychopharmacol Biol Psychiatry 2004, 28(8): I 22 I - I247.

21. Epstein LH, Temple JL, Neaderhiser BJ, Salis RJ, Erbe RW, Leddy J: Food reinforcement, the dopamine $D 2$ receptor genotype, and energy intake in obese and nonobese humans. Behav Neurosci 2007, I 2 I (5):877-886.

22. Kohnke MD, Batra A, Kolb W, Kohnke AM, Lutz U, Schick S, Gaertner I: Association of the dopamine transporter gene with alcoholism. Alcohol Alcohol 2005, 40(5):339-342.

23. Stapleton JA, Sutherland G, O'Gara C: Association between dopamine transporter genotypes and smoking cessation: a meta-analysis. Addict Biol 2007, I 2(2):22I-226.

24. Epstein LH, Jaroni JL, Paluch RA, Leddy JJ, Vahue HE, Hawk L, Wileyto EP, Shields PG, Lerman C: Dopamine transporter genotype as a risk factor for obesity in African-American smokers. Obes Res 2002, I 0( I 2): I 232-1240.

25. Morton LM, Wang SS, Bergen AW, Chatterjee N, Kvale P, Welch R, Yeager M, Hayes RB, Chanock SJ, Caporaso NE: DRD2 genetic variation in relation to smoking and obesity in the Prostate, Lung, Colorectal, and Ovarian Cancer Screening Trial. Pharmacogenet Genomics 2006, I6(12):901-910.

26. Noble EP: Addiction and its reward process through polymorphisms of the D2 dopamine receptor gene: a review. Eur Psychiatry 2000, I 5(2):79-89.

27. Prorok PC, Andriole GL, Bresalier RS, Buys SS, Chia D, Crawford ED, Fogel R, Gelmann EP, Gilbert F, Hasson MA, Hayes RB, Johnson CC, Mandel JS, Oberman A, O'Brien B, Oken MM, Rafla S, Reding D, Rutt W, Weissfeld JL, Yokochi L, Gohagan JK, Prostate, Lung, Colorectal and Ovarian Cancer Screening Trial Project Team: Design of the Prostate, Lung, Colorectal and Ovarian (PLCO) Cancer Screening Trial. Control Clin Trials 2000, 2 I (6 Suppl):273S-309S.

28. Wang SS, Morton LM, Bergen AW, Lan EZ, Chatterjee N, Kvale P, Hayes RB, Chanock S], Caporaso NE: Genetic variation in catechol-O-methyltransferase (COMT) and obesity in the prostate, lung, colorectal, and ovarian (PLCO) cancer screening trial. Hum Genet 2007, I 22(I):4 I-49.

29. Packer BR, Yeager M, Staats B, Welch R, Crenshaw A, Kiley M, Eckert A, Beerman M, Miller E, Bergen A, Rothman N, Strausberg R, Chanock SJ: SNP500Cancer: a public resource for sequence validation and assay development for genetic variation in candidate genes. Nucleic Acids Res 2004:D528-532.

30. Gelernter J, Yu Y, Weiss R, Brady K, Panhuysen C, Yang BZ, Kranzler HR, Farrer L: Haplotype spanning TTCI 2 and ANKKI, flanked by the DRD2 and NCAMI loci, is strongly associated to nicotine dependence in two distinct American populations. Hum Mol Genet 2006, I 5(24):3498-3507.

3I. Yang BZ, Kranzler HR, Zhao H, Gruen JR, Luo X, Gelernter J: Association of haplotypic variants in DRD2, ANKKI, TTCI 2 and NCAMI to alcohol dependence in independent case control and family samples. Hum Mol Genet 2007, I 6(23):2844-2853.

32. Wang GJ, Volkow ND, Thanos PK, Fowler JS: Similarity between obesity and drug addiction as assessed by neurofunctional imaging: a concept review. J Addict Dis 2004, 23(3):39-53. 
33. Brookes KJ, Neale BM, Sugden K, Khan N, Asherson P, D'Souza UM: Relationship between VNTR polymorphisms of the human dopamine transporter gene and expression in post-mortem midbrain tissue. Am J Med Genet B Neuropsychiatr Genet 2007, I44B(8): 1070-1078.

34. Inoue-Murayama M, Adachi S, Mishima N, Mitani H, Takenaka O, Terao K, Hayasaka I, Ito S, Murayama Y: Variation of variable number of tandem repeat sequences in the 3 '-untranslated region of primate dopamine transporter genes that affects reporter gene expression. Neurosci Lett 2002, 334(3):206-2I0.

35. Mill J, Asherson P, Browes C, D'Souza U, Craig I: Expression of the dopamine transporter gene is regulated by the 3' UTR VNTR: Evidence from brain and lymphocytes using quantitative RT-PCR. Am J Med Genet 2002, I I 4(8):975-979.

36. VanNess SH, Owens MJ, Kilts CD: The variable number of tandem repeats element in DATI regulates in vitro dopamine transporter density. BMC Genet 2005, 6:55.

37. Heinz A, Goldman D, Jones DW, Palmour R, Hommer D, Gorey JG, Lee $K S$, Linnoila M, Weinberger DR: Genotype influences in vivo dopamine transporter availability in human striatum. Neuropsychopharmacology 2000, 22(2): 133-139.

38. Jacobsen LK, Staley JK, Zoghbi SS, Seibyl JP, Kosten TR, Innis RB, Gelernter I: Prediction of dopamine transporter binding availability by genotype: a preliminary report. Am J Psychiatry 2000, I57(10): $1700-1703$.

39. Martinez D, Gelernter J, Abi-Dargham A, van Dyck CH, Kegeles L, Innis $R B$, Laruelle $M$ : The variable number of tandem repeats polymorphism of the dopamine transporter gene is not associated with significant change in dopamine transporter phenotype in humans. Neuropsychopharmacology 200I, 24(5):553-560.

40. van Dyck CH, Malison RT, Jacobsen LK, Seibyl JP, Staley JK, Laruelle M, Baldwin RM, Innis RB, Gelernter J: Increased dopamine transporter availability associated with the 9-repeat allele of the SLC6A3 gene. I Nucl Med 2005, 46(5):745-75I.

41. Need AC, Ahmadi KR, Spector TD, Goldstein DB: Obesity is associated with genetic variants that alter dopamine availability. Ann Hum Genet 2006, 70(Pt 3):293-303.

42. Fuemmeler BF, Agurs-Collins TD, McClernon FJ, Kollins SH, Kail ME, Bergen AW, Ashley-Koch AE: Genes implicated in serotonergic and dopaminergic functioning predict BMI categories. Obesity (Silver Spring) 2008, 16(2):348-355.

43. Li S, Loos RJ: Progress in the genetics of common obesity: size matters. Curr Opin Lipidol 2008, 19(2): | |3-121.

44. Frank GK, Bailer UF, Henry SE, Drevets W, Meltzer CC, Price JC Mathis CA Wagner A, Hoge J, Ziolko S, Barbarich-Marsteller N, Weissfeld L, Kaye WH: Increased dopamine D2/D3 receptor binding after recovery from anorexia nervosa measured by positron emission tomography and [I I c]raclopride. Biol Psychiatry 2005, 58(II):908-912.

45. Bergen AW, Yeager M, Welch RA, Haque K, Ganjei JK, Bree MB van den, Mazzanti C, Nardi I, Fichter MM, Halmi KA, Kaplan AS, Strober M, Treasure J, Woodside DB, Bulik CM, Bacanu SA, Devlin B, Berrettini WH, Goldman D, Kaye WH: Association of multiple DRD2 polymorphisms with anorexia nervosa. Neuropsychopharmacology 2005, 30(9): $1703-1710$.

46. Bachner-Melman R, Lerer E, Zohar AH, Kremer I, Elizur Y, Nemanov L, Golan M, Blank S, Gritsenko I, Ebstein RP: Anorexia nervosa, perfectionism, and dopamine D4 receptor (DRD4). Am J Med Genet B Neuropsychiatr Genet 2007, I44B(6):748-756.

47. Duan J, Wainwright MS, Comeron JM, Saitou N, Sanders AR, Gelernter J, Gejman PV: Synonymous mutations in the human dopamine receptor D2 (DRD2) affect mRNA stability and synthesis of the receptor. Hum Mol Genet 2003, I 2(3):205-216.

48. Greenwood TA, Alexander M, Keck PE, McElroy S, Sadovnick AD, Remick RA, Shaw SH, Kelsoe JR: Segmental linkage disequilibrium within the dopamine transporter gene. Mol Psychiatry 2002, 7(2): $165-173$

49. Flegal KM, Troiano RP, Pamuk ER, Kuczmarski RJ, Campbell SM: The influence of smoking cessation on the prevalence of overweight in the United States. N Engl I Med 1995 333(18): $1165-1170$.

50. From the Centers for Disease Control and Prevention. Annual smoking attributable mortality, years of potential life lost and economic costs - United States, 1995-1999. JAMA 2002, 287( ( 8):2355-2356.
51. Adams KF, Schatzkin A, Harris TB, Kipnis V, Mouw T, Ballard-Barbash R, Hollenbeck A, Leitzmann MF: Overweight, obesity, and mortality in a large prospective cohort of persons 50 to $7 \mathrm{I}$ years old. N Engl J Med 2006, 355(8):763-778.

52. Calle EE, Rodriguez C, Walker-Thurmond K, Thun MJ: Overweight, obesity, and mortality from cancer in a prospectively studied cohort of U.S. adults. N Engl J Med 2003, 348(1 7): I625-I638.

53. Novotny TE, Giovino GA: Tobacco Use. In Chronic disease epidemiology and control Volume 59. Edited by: Brownson RC, Remington PL, Davis JR. Washington, DC: American Public Health Association; 1998.

54. Hukkanen J, Jacob P 3rd, Benowitz NL: Metabolism and disposition kinetics of nicotine. Pharmacol Rev 2005, 57(I):79-II5.

55. Klesges RC, Meyers AW, Klesges LM, La Vasque ME: Smoking, body weight, and their effects on smoking behavior: a comprehensive review of the literature. Psychol Bull 1989, 106(2):204-230.

56. Kenny PJ, Markou A: Neurobiology of the nicotine withdrawal syndrome. Pharmacol Biochem Behav 200I, 70(4):53I-549.

57. Erblich J, Lerman C, Self DW, Diaz GA, Bovbjerg DH: Stressinduced cigarette craving: effects of the DRD2 Taql RFLP and SLC6A3 VNTR polymorphisms. Pharmacogenomics J 2004, 4(2): 102-109.

58. Erblich J, Lerman C, Self DW, Diaz GA, Bovbjerg DH: Effects of dopamine D2 receptor (DRD2) and transporter (SLC6A3) polymorphisms on smoking cue-induced cigarette craving among African-American smokers. Mol Psychiatry 2005, I0(4):407-4I4.

59. Davis C, Woodside DB: Sensitivity to the rewarding effects of food and exercise in the eating disorders. Compr Psychiatry 2002, 43(3): $189-194$.

\section{Pre-publication history}

The pre-publication history for this paper can be accessed here:

http://www.biomedcentral.com/1471-2350/10/9/prepub

Publish with Biomed Central and every scientist can read your work free of charge

"BioMed Central will be the most significant development for disseminating the results of biomedical research in our lifetime. "

Sir Paul Nurse, Cancer Research UK

Your research papers will be:

- available free of charge to the entire biomedical community

- peer reviewed and published immediately upon acceptance

- cited in PubMed and archived on PubMed Central

- yours - you keep the copyright 